\title{
Performance Evaluation of Aqua Planter for Groundnut Crop
}

\author{
Bollavathi Laxman ${ }^{1 *}$, S. Joseph Reddy ${ }^{2}$, K. Madhusudhana Reddy ${ }^{3}$ and \\ Er.G. Veera Prasad ${ }^{4}$ \\ ${ }^{1}$ AICRP on FIM Scheme, Rajendranagar, Hyderabad, T.S., India \\ ${ }^{2}$ (Agri. Engg), RARS, Nandyala, A.P., India \\ ${ }^{3}$ (Agri. Engg), S.V Agricultural College, Tirupathi, A.P., India \\ ${ }^{4}$ AICRP on Farm Implements and Machinery, CAE, Bapatla, A.P., India \\ *Corresponding author
}

\section{A B S T R A C T}

Dry land agriculture plays an important role in the progress of Indian agriculture. The farmers are struggling to maintain timeliness in different unit operations of groundnut to take advantage of favorable situation in dry land conditions of Andhra Pradesh state. It is

Keywords

Planter, Seed rate,

Discharge, Field

efficiency, Yield

Article Info

Accepted:

04 May 2018

Available Online:

10 June 2018 observed that the yields are expected to decrease by 10-15 per cent, if sowing is delayed by one week, under rain-fed situation. It is absolutely crucial for the seeds that moisture be available in the first few days itself after sowing to achieve 100 per cent germination. Aqua sowing is the simultaneous sowing of seeds and delivery of an equitable quantum of water, just right for the seeds to germinate irrespective of whether it rains or not for the next few days. This is a new technology developed for the benefits of dryland farmers and specially for sowing of seeds during contingency season of delayed monsoon. Seed rates for the groundnut was $105.47,108.46,118.55 \mathrm{~kg} \mathrm{ha}^{-1}$ with vertical, inclined and horizontal plate seed metering mechanisms respectively. The vertical plate metering mechanism has been selected for sowing in the field. The highest application of water in a test plot of $30 \mathrm{~m}$ x $30 \mathrm{~m}$ was found to be $120 \mathrm{lit} / \mathrm{min}$. The field capacity was found to be $0.145 \mathrm{ha} \mathrm{h}^{-1}$ for groundnut with field efficiency of 88.90 per cent at an average speed of $2.72 \mathrm{kmph}$ for an aqua planter. The highest pod yield was found to be $619.38 \mathrm{~kg} \mathrm{ha}^{-1}$ with discharge rate of 120 lit/min. The cost of sowing with tractor drawn aqua planter was Rs. 751.42 per hour.

\section{Introduction}

Agriculture is one of the most important sectors of Indian economy both in terms of gross national product and number of productive workers employed. Dry farming or dry land farming is a practice of growing a profitable crop without irrigation in areas, which receive an annual rainfall of $500 \mathrm{~mm}$ or even less. Dry lands contribute more than 40 per cent food grains ( 80 per cent maize, 95 per cent of pearl millet and sorghum). About 95 per cent of pulses and 75.5 per cent of oilseeds are also grown in these areas. Thus, dry lands and rain fed farming will continue to play a dominant role in agricultural production. Groundnut (Arachis hypogaea L.) is the major oil seed crop in India and it plays a major role in bridging the vegetable oil deficit in the country. Groundnut is an important protein 
crop in India, it raised mostly as a rain fed Kharif crop, being sown from May to June, depending on the monsoon rains. In some areas, or where the monsoon is delayed, it is sown as late August or early September (Madhusudhana, 2013).

The crop can be grown successfully in places receiving a minimum rainfall of $500 \mathrm{~mm}$ and a maximum rainfall of $1250 \mathrm{~mm}$. The area under groundnut crop is $4.70 \mathrm{M}$ ha, which occupies $45 \%$ area and $55 \%$ of the total oil seeds production i.e., 6.60 MT in India (Economic Survey of India, 2015). The area under Groundnut alone accounted for $77.21 \%$ of the total area under oil seeds during 201415 in Andhra Pradesh (Directorate of Economics and Statistics, 2015). The effectiveness of rainfall in crop production depends mainly on commencement of sowing rains and amount and distribution of rainfall during the season (Sahu et al., 2004).

It is absolutely crucial for the seeds that moisture be available in the first few days itself after sowing to achieve 100 per cent germination. Aqua sowing is the simultaneous sowing of seeds and delivery of an equitable quantum of water, just right for the seeds to germinate irrespective of whether it rains or not for the next few days. This is a new technology developed for the benefits of dryland farmers, and specially for sowing of seeds during a contingency season of delayed monsoon.

\section{Materials and Methods}

\section{Laboratory evaluation of different metering mechanisms}

The laboratory experiments were conducted to calibrate different seed metering mechanisms for groundnut with commercially available tractor drawn planters at Agricultural Research Station, Ananthapuramu. The specifications of commercially available seed metering mechanism were reported in Table 1.

\section{Groundnut}

The evaluation of groundnut seed was conducted under laboratory conditions to determine the discharge rate (seed rate).

\section{Determination of seed rate for different seed metering mechanisms}

It was necessary to calibrate the planters before conducting field test for groundnut seeds to find the desired seed rate. The planters were calibrated by the standard method (as per BIS test code 6316: 1993).

\section{Performance of tractor drawn aqua planter}

Tractor drawn aqua planter was developed at Agricultural Research Station, Ananthapuramu. It consists of

Main frame

Seed hopper

Seed hopper holding pipes

Seed metering mechanism

Seed tube

Furrow opener

Power transmission system

Depth control wheels

Water tank (Fig. 1)

\section{Main frame}

Main frame of planter was made of MS angular plates of size $1500 \times 80 \mathrm{~mm}$. All the other parts of planter were attached to main frame.

\section{Seed hopper}

The seed hopper was made of MS sheet. The overall dimensions of the hopper were $300 \mathrm{x}$ $230 \times 350 \mathrm{~mm}$. An adjustable gate was 
provided below the hoper to allow the seeds into metering mechanism.

\section{Seed metering device}

A vertical plate seed metering device was used to meter the seed. Diameter of each plate is 96 $\mathrm{mm}$ with thickness of $13 \mathrm{~mm}$ for groundnut and $7 \mathrm{~mm}$ for red gram and having 10 cells around its periphery.

\section{Seed tube}

Seed tube is made of plastic and having diameter of $4.45 \mathrm{~cm}$. The main function of seed tube is to deliver seed from metering device to boot.

\section{Furrow opener}

Shovel type furrow opener was used as furrow opener and which was made of MS flat plate $60 \mathrm{~mm}$ width, $5 \mathrm{~mm}$ thickness and length 280 $\mathrm{mm}$. It was attached to one end of tyne with bolts and nuts.

\section{Power transmission system}

A peg type ground wheel was provided for power transmission. Sprockets along with chain were used to transmit power from ground wheel to seed metering device.

\section{Depth control wheels}

Two depth control wheels were attached on each side of the planter. The wheels provide balance to the planter and helps in maintaining proper depth of sowing.

\section{Water tank}

An elliptical shaped about 4000 liters capacity of tank has been used for water application while sowing. The overall dimensions of the tank were $2750 \times 1720 \times 1220 \mathrm{~mm}$.

\section{Calibration of water application system}

Calibration was done in the laboratory, to determine the time required for emptying tank when valve is fully open.

Also determined the valve positions for discharging of water at 60,90 and $120 \mathrm{~L} / \mathrm{min}$ respectively.

The application rate of water per ha was calculated by considering effective field capacity. Water application rate is calculated by using formula given below.

Application rate, $\mathrm{L} / \mathrm{ha}=\frac{\frac{\text { Volume of water applied }}{\text { Area of test plot }}}{\text { An }}$

Performance evaluation of tractor drawn aqua planter

The performance of tractor drawn aqua planter was evaluated under field conditions. The parameters such as soil, operational, sowing, crop and yield parameters were observed during the field tests. The specifications of the tractor drawn aqua planter are presented in Table 2.

\section{Machine and operational parameters}

\section{Speed of operation}

To determine the speed of operation, planter was operated on a row of $25 \mathrm{~m}$ length. A stop watch was used to record the time for the planter to traverse the marked run so that the speed of travel was computed in $\mathrm{m} \mathrm{s}^{-1}$.

\section{Effective field capacity}

It is the actual area covered by the planter based on its total time consumed and actual working width under field conditions.

Field capacity $\left(\right.$ ha $\left.\mathrm{h}^{-1}\right)=$ Actual area covered/total time consumed 


\section{Theoretical field capacity}

Theoretical field capacity is the rate of field coverage of the implement, based on 100 per cent of time at the rated speed and covering 100 per cent of its rated width.

The theoretical field capacity was determined using the following formula.

Theoretical field capacity, ha $\mathrm{h}^{-1}=$ Width $(\mathrm{m}) X$ Speed $(\mathrm{km} / \mathrm{h})$

10

\section{Field efficiency}

Field efficiency is the ratio of effective field capacity to theoretical field capacity.

It was determined by the following formula (Ashok et al., 2012)

Field efficiency, $\%=$ Effective filled capacity. (ha/h)

Theoretical field capacity, $(\mathrm{ha} / \mathrm{h}) \mathrm{X} 100$

\section{Sowing parameters}

\section{Seed rate}

The seed rate was determined by taking the weight of seed before and after sowing operation.

Then subtracted the final weight of seed from initial weight of seed so that the seed rate was obtained and the results were expressed in terms of $\mathrm{kg} \mathrm{ha}^{-1}$.

\section{Depth of sowing}

Depth of sowing of seeds was determined with the help of steel scale of $0.3 \mathrm{~m}$.

Twenty observations were taken for each plot and their mean was calculated to represent the depth of sowing.

\section{Seed to seed spacing}

Seed to seed spacing was measured by a steel scale of $0.30 \mathrm{~m}$ length after sowing. The soil was removed carefully without disturbing the seeds at minimum five random places taken for three different discharge rates 60,90 and $120 \mathrm{~L} / \mathrm{min}$ in a row and the mean was determined to represent seed to seed spacing.

\section{Crop parameters}

\section{Average plant population}

The average plant population was determined by counting number of plants per square meter at five random places and the mean value represented the average plant population.

\section{Seed to seed spacing}

Seed to seed spacing was measured by a steel scale of $0.30 \mathrm{~m}$ length after sowing. The soil was removed carefully without disturbing the seeds at minimum five random places taken for three different discharge rates 60, 90 and $120 \mathrm{~L} / \mathrm{min}$ in a row and the mean was determined to represent seed to seed spacing.

\section{Pod yield}

Pod yield was determined from $1 \mathrm{~m}^{2}$ area. Five random observations were taken from field and thoroughly dried in sun. After completion of sun drying, the pods are separated from plants and the weight of pods for groundnut seed were recorded and converted to $\mathrm{kg} \mathrm{ha}^{-1}$.

\section{Cost economics}

The cost economics of planter was estimated by considering fixed and operational costs of planter and power source. The cost of operation is based on the prevailing market rates during the season and location. (IS 9164:1979). 


\section{Results and Discussion}

The results have been presented under the following heads:

\section{Seed rate of groundnut}

Seed rates for the groundnut seed observed were 105.47, 108.46 and $118.55 \mathrm{~kg} \mathrm{ha}^{-1}$ respectively for the different seed metering mechanisms viz. vertical plate, inclined plate and horizontal plate metering mechanisms respectively in the calibration test. The results are presented in Table 3 to 5.

\section{Water application system}

The results of aqua planter for groundnut are given in Table 6. The average discharges of water taps are adjusted for 60, 90 and 120 $\mathrm{L} / \mathrm{min}$. The application rate of water in a test plot of $30 \mathrm{~m} \times 30 \mathrm{~m}$ was found to be highest for $120 \mathrm{~L} / \mathrm{min}$ i.e. 49655.17 liters at an average speed of $2.72 \mathrm{kmph}$ groundnut respectively.

\section{Field performance of the aqua planter}

The aqua planter was field tested for its machine parameters and crop parameters in research field of plot 30 x $30 \mathrm{~m}^{2}$ at
Agricultural Research station, Ananthapuramu.

The field performance of the Aqua planter like the effective field capacity and field efficiency was observed as $0.145 \mathrm{ha} / \mathrm{h}$ and 88.90 per cent respectively. During the effective field capacity was lower. It was observed during field operation, the care taken to reduce the time for turning, clogging and adjustments of the aqua planter resulted in higher field efficiency (Table 7).

Further it was observed that depth of seed placement was $51 \mathrm{~mm}$ with row to row spacing of $228 \mathrm{~mm}$. The seed rate was found to be $105.47 \mathrm{~kg} / \mathrm{ha}$. The pod yield obtained was $619.38 \mathrm{~kg} / \mathrm{ha}$ and the cost of tractor drawn aqua planter is Rs. 751.42 per hour.

The performance of tractor drawn aqua planter for groundnut is developed under Agricultural Research Station, Ananthapuramu. An attempt was made to evaluate the performance of aqua planter under field conditions and study of the performance of existing seed metering mechanisms groundnut seeds under laboratory conditions various parameters i.e. seed rate, water application rate, field efficiency, seed to seed spacing, depth of sowing and crop yield were studied. Following were the conclusions that are drawn from the study

Table.1 Specifications of the commercially available seed metering mechanisms

\begin{tabular}{|c|c|c|c|c|c|}
\hline S. No & $\begin{array}{c}\text { Seed metering } \\
\text { mechanism }\end{array}$ & $\begin{array}{c}\text { No. of } \\
\text { furrow } \\
\text { openers }\end{array}$ & $\begin{array}{c}\text { Row } \\
\text { spacing } \\
(\mathbf{m})\end{array}$ & $\begin{array}{c}\text { Operating } \\
\text { width }(\mathbf{m})\end{array}$ & $\begin{array}{c}\text { Dimensions of } \\
\text { planter/seed } \\
\text { drill (lxbxh) } \\
(\mathbf{c m})\end{array}$ \\
\hline $\mathbf{1}$ & Inclined plate & 8 & 0.30 & 2.4 & $255 \times 97 \times 110$ \\
\hline $\mathbf{2}$ & Horizontal plate & 8 & 0.30 & 2.4 & $255 \times 97 \times 128$ \\
\hline $\mathbf{3}$ & Vertical plate & 8 & 0.30 & 2.4 & $255 \times 98 \times 157$ \\
\hline
\end{tabular}


Table.2 Specifications of tractor drawn aqua planter

\begin{tabular}{|c|l|l|}
\hline S. No & \multicolumn{1}{|c|}{ Particulars } & \multicolumn{1}{c|}{ Specifications } \\
\hline $\mathbf{1 .}$ & Power source & $>40 \mathrm{H.P}$ tractor \\
\hline $\mathbf{2 .}$ & Number of furrows & 5 \\
\hline $\mathbf{3 .}$ & Row to row spacing & $30 \mathrm{~cm}$ \\
\hline $\mathbf{4 .}$ & Effective working width & $150 \mathrm{~cm}$ \\
\hline $\mathbf{5 .}$ & Type of seed metering mechanism & Vertical plate \\
\hline $\mathbf{6 .}$ & Overall height and width & $145 \times 65 \times 120 \mathrm{~cm}$ \\
\hline $\mathbf{7 .}$ & Seed box capacity & $8 \mathrm{~kg}$ \\
\hline $\mathbf{8 .}$ & Depth of sowing for groundnut and red gram & $5-7 \mathrm{~cm}$ and $5-6$ \\
\hline $\mathbf{9 .}$ & Seed to seed spacing in a row & $10 \mathrm{~cm}$ \\
\hline $\mathbf{1 0 .}$ & Type of furrow opener & Shovel type \\
\hline $\mathbf{1 1 .}$ & Water tank capacity & 4000 liters \\
\hline $\mathbf{1 2}$. & Cost & Rs. $1,00,000 /-$ \\
\hline
\end{tabular}

Table.3 Calibration of the vertical plate metering mechanism for groundnut

\begin{tabular}{|c|c|c|c|c|c|c|c|c|c|c|c|}
\hline \multirow[t]{2}{*}{$\begin{array}{l}\text { Test } \\
\text { no. }\end{array}$} & \multicolumn{8}{|c|}{$\begin{array}{c}\text { Weight of seed discharged in } 128 \text { revolution of ground } \\
\text { wheel }\end{array}$} & \multirow{2}{*}{$\begin{array}{c}\text { Weight of } \\
\text { seed } \\
\text { collected } \\
\text { from all } \\
\text { furrow } \\
\text { openers (kg) }\end{array}$} & \multirow{2}{*}{$\begin{array}{c}\text { Seed } \\
\text { rate }(\mathbf{k g} \\
\left.\text { ha }^{-1}\right)\end{array}$} & \multirow{2}{*}{$\begin{array}{l}\text { Average } \\
\text { seed rate } \\
\left(\mathrm{kg} \mathrm{ha}^{-1}\right)\end{array}$} \\
\hline & $\begin{array}{c}\text { Row } \\
1\end{array}$ & $\begin{array}{c}\text { Row } \\
2\end{array}$ & $\begin{array}{c}\text { Row } \\
3\end{array}$ & $\begin{array}{c}\text { Row } \\
4\end{array}$ & $\begin{array}{c}\text { Row } \\
5\end{array}$ & $\begin{array}{c}\text { Row } \\
6\end{array}$ & $\begin{array}{c}\text { Row } \\
7\end{array}$ & $\begin{array}{c}\text { Row } \\
8\end{array}$ & & & \\
\hline 1 & 0.42 & 0.52 & 0.49 & 0.47 & 0.69 & 0.49 & 0.56 & 0.57 & 4.21 & 105.12 & \multirow[t]{5}{*}{105.47} \\
\hline 2 & 0.43 & 0.49 & 0.47 & 0.46 & 0.71 & 0.44 & 0.53 & 0.65 & 4.18 & 104.37 & \\
\hline 3 & 0.45 & 0.55 & 0.48 & 0.43 & 0.67 & 0.48 & 0.54 & 0.63 & 4.23 & 105.62 & \\
\hline 4 & 0.44 & 0.53 & 0.46 & 0.45 & 0.67 & 0.47 & 0.56 & 0.63 & 4.21 & 105.12 & \\
\hline 5 & 0.45 & 0.54 & 0.47 & 0.47 & 0.68 & 0.48 & 0.55 & 0.65 & 4.29 & 107.11 & \\
\hline
\end{tabular}

Table.4 Calibration of the inclined plate metering mechanism for groundnut

\begin{tabular}{|c|c|c|c|c|c|c|c|c|c|c|c|}
\hline \multirow[t]{2}{*}{$\begin{array}{l}\text { Test } \\
\text { no. }\end{array}$} & \multicolumn{8}{|c|}{$\begin{array}{l}\text { Weight of seed discharged in } 128 \text { revolution of ground } \\
\text { wheel }\end{array}$} & \multirow{2}{*}{$\begin{array}{l}\text { Weight of } \\
\text { seed collected } \\
\text { from all } \\
\text { furrow } \\
\text { openers (kg) }\end{array}$} & \multirow{2}{*}{$\begin{array}{c}\text { Seed } \\
\text { rate }(\mathbf{k g} \\
\left.\mathbf{h a}^{-1}\right)\end{array}$} & \multirow{2}{*}{$\begin{array}{l}\text { Average } \\
\text { seed rate } \\
\left(\mathrm{kg} \mathrm{ha}^{-1}\right)\end{array}$} \\
\hline & $\begin{array}{c}\text { Row } \\
1\end{array}$ & $\begin{array}{c}\text { Row } \\
2\end{array}$ & $\begin{array}{c}\text { Row } \\
3\end{array}$ & $\begin{array}{c}\text { Row } \\
4\end{array}$ & $\begin{array}{c}\text { Row } \\
5\end{array}$ & $\begin{array}{c}\text { Row } \\
6\end{array}$ & $\begin{array}{c}\text { Row } \\
7\end{array}$ & $\begin{array}{c}\text { Row } \\
8\end{array}$ & & & \\
\hline 1 & 0.45 & 0.54 & 0.52 & 0.51 & 0.5 & 0.71 & 0.51 & 0.59 & 4.33 & 108.11 & \multirow[t]{5}{*}{108.46} \\
\hline 2 & 0.46 & 0.56 & 0.51 & 0.52 & 0.52 & 0.72 & 0.52 & 0.58 & 4.39 & 109.61 & \\
\hline 3 & 0.46 & 0.55 & 0.51 & 0.5 & 0.5 & 0.71 & 0.53 & 0.59 & 4.35 & 108.61 & \\
\hline 4 & 0.45 & 0.54 & 0.5 & 0.52 & 0.5 & 0.73 & 0.52 & 0.58 & 4.34 & 108.36 & \\
\hline 5 & 0.44 & 0.55 & 0.51 & 0.5 & 0.51 & 0.72 & 0.51 & 0.57 & 4.31 & 107.61 & \\
\hline
\end{tabular}


Table.5 Calibration of the horizontal plate metering mechanism for groundnut

\begin{tabular}{|c|c|c|c|c|c|c|c|c|c|c|c|}
\hline \multirow[t]{2}{*}{$\begin{array}{l}\text { Test } \\
\text { no. }\end{array}$} & \multicolumn{8}{|c|}{$\begin{array}{c}\text { Weight of seed discharged in } 128 \text { revolution of ground } \\
\text { wheel }\end{array}$} & \multirow{2}{*}{$\begin{array}{l}\text { Weight of } \\
\text { seed } \\
\text { collected } \\
\text { from all } \\
\text { furrow } \\
\text { openers (kg) }\end{array}$} & \multirow{2}{*}{$\begin{array}{c}\text { Seed } \\
\text { rate }(\mathrm{kg} \\
\left.\text { ha }^{-1}\right)\end{array}$} & \multirow{2}{*}{$\begin{array}{l}\text { Average } \\
\text { seed rate } \\
\left(\mathrm{kg} \mathrm{ha}^{-1}\right)\end{array}$} \\
\hline & $\begin{array}{c}\text { Row } \\
1\end{array}$ & $\begin{array}{c}\text { Row } \\
2\end{array}$ & $\begin{array}{c}\text { Row } \\
3\end{array}$ & $\begin{array}{c}\text { Row } \\
4\end{array}$ & $\begin{array}{c}\text { Row } \\
5\end{array}$ & $\begin{array}{c}\text { Row } \\
6\end{array}$ & $\begin{array}{c}\text { Row } \\
7\end{array}$ & $\begin{array}{c}\text { Row } \\
8\end{array}$ & & & \\
\hline 1 & 0.56 & 0.59 & 0.61 & 0.6 & 0.61 & 0.61 & 0.62 & 0.53 & 4.73 & 118.10 & \multirow[t]{5}{*}{118.55} \\
\hline 2 & 0.58 & 0.6 & 0.6 & 0.62 & 0.6 & 0.6 & 0.61 & 0.54 & 4.75 & 118.60 & \\
\hline 3 & 0.57 & 0.61 & 0.63 & 0.62 & 0.62 & 0.61 & 0.62 & 0.51 & 4.79 & 119.60 & \\
\hline 4 & 0.56 & 0.6 & 0.62 & 0.6 & 0.62 & 0.63 & 0.61 & 0.52 & 4.76 & 118.85 & \\
\hline 5 & 0.55 & 0.61 & 0.61 & 0.61 & 0.61 & 0.61 & 0.6 & 0.51 & 4.71 & 117.60 & \\
\hline
\end{tabular}

Table.6 Calibration results of tractor drawn aqua planter for groundnut

\begin{tabular}{|c|c|c|c|c|c|}
\hline \multirow[t]{2}{*}{ S. No. } & \multirow{2}{*}{$\begin{array}{l}\text { Expected } \\
\text { discharge } \\
\text { L/min }\end{array}$} & \multicolumn{2}{|c|}{$\begin{array}{l}\text { Obtained discharge } \\
\text { (Mean) }\end{array}$} & \multirow{2}{*}{$\begin{array}{c}\text { Volume of } \\
\text { water given in } \\
\mathbf{3 0} \text { m X } 30 \text { m } \\
\text { plot (liter) }\end{array}$} & \multirow[t]{2}{*}{$\begin{array}{c}\text { Application rate, } \\
\text { liter/ha }\end{array}$} \\
\hline & & Tap1 & Tap2 & & \\
\hline 1 & 60 & 60.33 & 60.00 & 2234.48 & 24827.58 \\
\hline 2 & 90 & 89.33 & 91.00 & 3351.72 & 37241.37 \\
\hline 3 & 120 & 120.0 & 120.33 & 4468.96 & 49655.17 \\
\hline
\end{tabular}

Fig.1 Water tank

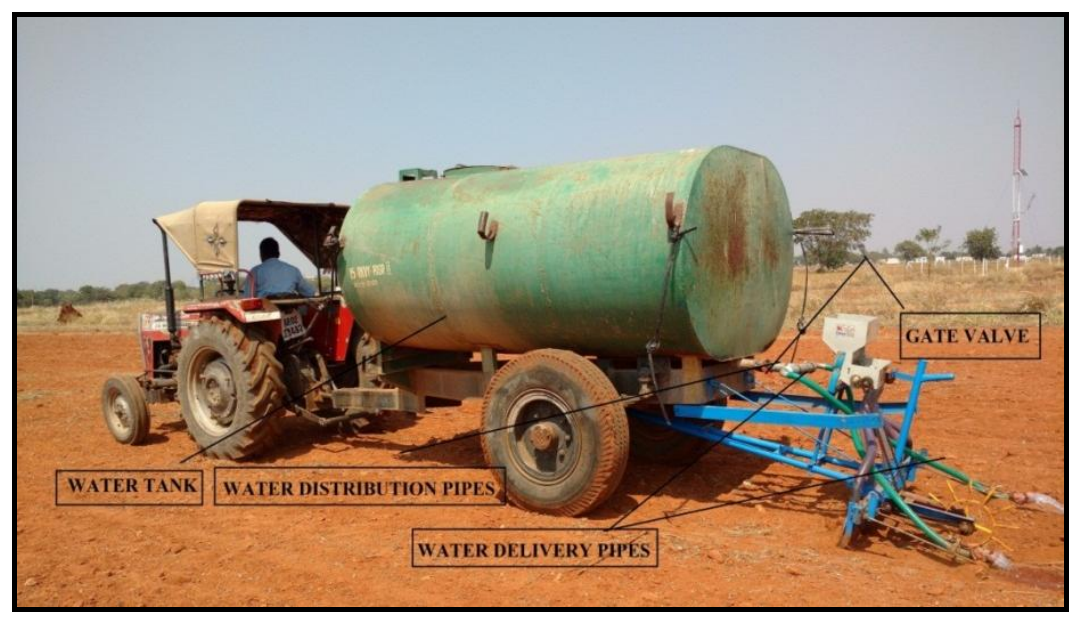


Table.7 Field performance of tractor drawn aqua planter

\begin{tabular}{|c|l|c|}
\hline S. No. & \multicolumn{1}{|c|}{ Parameters } & Aqua planter for groundnut \\
\hline $\mathbf{1}$ & Plot area, $\mathrm{m}^{2}$ & 900 \\
\hline $\mathbf{2}$ & Speed of operation, $\mathrm{kmph}$ & 2.72 \\
\hline $\mathbf{3}$ & Effective field capacity, $\mathrm{ha}^{-1}$ & 0.145 \\
\hline $\mathbf{4}$ & Theoretical field capacity, $\mathrm{ha} \mathrm{h}^{-1}$ & 0.163 \\
\hline $\mathbf{5}$ & Field efficiency, \% & 88.90 \\
\hline $\mathbf{6}$ & Plant population, $/ \mathrm{m}^{2}$ & 22.80 \\
\hline $\mathbf{7}$ & Seed rate, $\mathrm{kg} / \mathrm{ha}$ & 105.47 \\
\hline $\mathbf{8}$ & Depth of seed placement, $\mathrm{mm}$ & 51 \\
\hline $\mathbf{9}$ & Row to row spacing, $\mathrm{mm}$ & 228 \\
\hline $\mathbf{1 0}$ & Seed to seed spacing, $\mathrm{mm}$ & 100.8 \\
\hline $\mathbf{1 1}$ & Pod yield, $\mathrm{kg} / \mathrm{ha}$ & 619.38 \\
\hline $\mathbf{1 2}$ & Cost analysis, Rs/hr & 751.42 \\
\hline
\end{tabular}

Seed rates for the groundnut seed observed were $105.47,108.46, \quad 118.55 \mathrm{~kg} \mathrm{ha}{ }^{-1}$ respectively for vertical, inclined and horizontal plate metering mechanisms respectively.

The breakage of groundnut seed was found to be less percentage in case of vertical plate metering mechanism. Hence vertical plate metering mechanism was selected for sowing in the field.

The application rate of water in a test plot of $30 \mathrm{~m} \times 30 \mathrm{~m}$ was found to be highest for 120 $\mathrm{L} / \mathrm{min}$ i.e. 49655.17 liters at an average speed of $2.7 \mathrm{kmph}$ groundnut.

The field capacity was found to be $0.145 \mathrm{ha} \mathrm{h}^{-}$ ${ }^{1}$ for groundnut with field efficiency of 88.90 per cent at an average speed of $2.72 \mathrm{kmph}$ for aqua planter.

The highest plant population per square meter and plant height in $\mathrm{cm}$ for was found to be 22.8 and 21.06 respectively with 120 liters discharge rates.
The highest pod yield obtained for groundnut was found to be $619.38 \mathrm{~kg} \mathrm{ha}^{-1}$ with discharge rate of $120 \mathrm{~L} / \mathrm{min}$ whereas the lowest pod yield was found to be $334.15 \mathrm{~kg} \mathrm{ha}^{-1}$ with discharge rate of $60 \mathrm{~L} / \mathrm{min}$.

The cost of sowing operation of aqua planter with tractor for groundnut was Rs. 751.42 per hour.

\section{References}

Ashoka, H.G., Jayanthi, B and Prashantha, G.M. 2012. Performance evaluation of power drawn six row groundnut planter. International Journal of Agricultural Engineering, 5 (2): 123-126.

BIS: IS: 6316:1993, Indian standard Test Code for Sowing Equipment-Seed-cumfertilizer Drill, New Delhi.

BIS: IS: 9164: 1979, Indian standard test code for Guide for Estimating Cost of Farm Machinery Operation, New Delhi.

DES, 2015. Directorate of Economics and Statistics, Andhra Pradesh, Agricultural Statistics at a glance, 2014-15. 
ESI, 2015. Economic Survey, India: Area, Production and Yield of Major crops.

Madhusudhana, B. 2013.A survey on area, production and productivity of groundnut crop in India. IOSR Journal of Economics and Finance, Vol. 1(3): 01-07.

Sahu, D.D., Golakiya, B.A and Patoliya, B.M. 2004. Impact of rainfall on the yield of rainfed groundnut. J. Agrometeorol, 6(2): 249-253.

\section{How to cite this article:}

Bollavathi Laxman, S. Joseph Reddy, K. Madhusudhana Reddy and Veera Prasad, Er. G. 2018. Performance Evaluation of Aqua Planter for Groundnut Crop. Int.J.Curr.Microbiol.App.Sci. 7(06): 810-818. doi: https://doi.org/10.20546/ijcmas.2018.706.095 